\title{
High connectivity across environmental gradients and implications for phenotypic plasticity in a marine plant
}

\author{
Eric Bricker ${ }^{1, *}$, Michelle Waycott ${ }^{2}$, Ainsley Calladine ${ }^{2}$, Joseph C. Zieman ${ }^{1}$ \\ ${ }^{1}$ Department of Environmental Sciences, Clark Hall, The University of Virginia, Charlottesville, Virginia 22903, USA \\ ${ }^{2}$ School of Marine and Tropical Biology, James Cook University, Townsville, Queensland 4811, Australia
}

\begin{abstract}
Thalassia testudinum is prevalent throughout the western tropical Atlantic, Gulf of Mexico, and Florida. This seagrass inhabits a wide range of coastal ecosystems and published data suggest significant morphological variation in T. testudinum across acute physicochemical environmental gradients. Strong reliance on vegetative growth provokes expectations of a clonal signature in the population structure of this species. We utilize high resolution genetic data to explore the population structure of $T$. testudinum and evaluate the basis for this species' plasticity as a function of a phenotypic versus a genotypic response. We studied one of the largest populations of T. testudinum, the Florida Bay system, and found that the population exhibited high levels of genetic diversity suggesting strong recruitment of sexually derived propagules. Allelic richness was high $\left(A_{\text {RIC }}=5.94\right.$ to 7.33) and expected heterozygosity was consistently high across our study subpopulations $\left(H_{\mathrm{e}}=0.558\right.$ to 0.673$)$. There was no evidence of inbreeding within subpopulations $\left(F_{\text {IS }}=0.02\right.$ to 0.13 ) and overall gene flow estimates were moderate to high $\left(N_{\mathrm{m}}=5.71\right)$. These data support $T$. testudinum in Florida Bay as a single metapopulation with high genetic connectivity among subpopulations. Models of migration utilizing Bayesian modeling revealed a distinct directionality to immigration counter to models of historical formation of Florida Bay. We also found no evidence that meadows formed genetic subpopulations suggesting morphological variability observed across environmental gradients represents norms of reaction within the genetically diverse, interbreeding metapopulation. We suggest $T$. testudinum evolved phenotypic plasticity as a general purpose trait under natural selection.
\end{abstract}

KEY WORDS: Population structure - Genetic structure - Seagrass · Phenotypic plasticity · Migration • Microsatellite $\cdot$ Thalassia testudinum Resale or republication not permitted without written consent of the publisher

\section{INTRODUCTION}

Many aquatic plant species, particularly marine plants, cover large geographic ranges (Cook 1985, Santamaria 2002, Les et al. 2003). Genetic connectivity between aquatic plant populations has the potential to be very high due to habitat continuity. This characteristic is not exclusive to plants, for example larval dispersion in aquatic species supports the suggestion that genetic connectivity can exist over extensive geographic ranges (McQuaid \& Phillips 2000, Planes et al.
2009). In addition to their broad geographic distributions, aquatic plants are also typified by having high phenotypic plasticity (Sculthorpe 1967). This trait is likely a result of natural selection pressures associated with potential stressors such as temperature, salinity, resource limitations, or other stress-inducing features of aquatic environments (Barrett et al. 1993). Such stressors have resulted in a significant reliance on vegetative growth by aquatic plants (Les et al. 2003). As a result, population structure is strongly influenced by the capacity of aquatic plants to form large, dis- 
persed, genets (i.e. clones) capable of long-term persistence (Reusch et al. 1999).

A rarely considered consequence of long-term persistence of genets is that older generations can occupy space for long periods, thus reducing recruitment opportunities for younger generations. As a result, immigration of outside recruits can be limited once populations become established. This means that the response of a plant to changing local environmental conditions will be highly dependent on its morphological flexibility. This is referred to as phenotypic plasticity. It is critical to distinguish between variability in the phenotype caused by ecological determinants, which results in species-wide phenotypic plasticity, and the alternative whereby plant variability is the result of selection-driven genetic diversity. The latter results in differentiation of traits among subpopulations (Schlichting 1986). One approach to evaluate the relative contribution of either strategy in a phenotypically variable species is to examine the population genetic structure of species inhabiting heterogeneous and homogeneous environments.

Marine angiosperms, or seagrasses, represent a group of species effectively adapted to survive extreme stressors inherent in the aquatic environment (Les et al. 1997). Their almost global distribution suggests most seagrass species have broad environmental tolerances. In addition, this makes seagrass species good candidates for investigation of the mechanistic indicators of how aquatic species respond phenotypically and genotypically to environmental variation. Thalassia testudinum Banks ex König (turtle grass) is a widespread tropical seagrass species. T. testudinum is distributed in coastal waters of the tropical and north subtropical West Atlantic region, and is prevalent throughout the
Caribbean, the Gulf of Mexico, Florida, and extending north to Bermuda (Moore 1963, den Hartog 1970). Across this range, $T$. testudinum dominates nearly all seagrass communities, forming widespread meadows that have the potential to persist for thousands of years (van Tussenbroek et al. 2006). Florida Bay contains one of the largest populations of $T$. testudinum as a network of discontinuous, often large $\left(>20 \mathrm{~km}^{2}\right)$ meadows that occupy almost $1900 \mathrm{~km}^{2}$ of the bay's $2100 \mathrm{~km}^{2}$ (Fourqurean et al. 2002). The species is known to have a high degree of phenotypic plasticity in its morphological response. Its phenotypic flexibility can be expressed as the relative investment in sexual or asexual propagation. But herein our reference to phenotypic plasticity refers to the species' capacity to express a variable, above-ground growth form; therefore leaf structure and leaf dimension reflect the phenotypic plasticity discussed in the present study.

Florida Bay is a shallow lagoon-type estuary enclosing a succession of nearly discrete basins. Basins constitute the physicochemical subunits of Florida Bay and are variable in their bathymetry, tidal flux, sediment depth, nutrient availability, water quality, salinity, and other key environmental characteristics (Madden et al. 2009). The eastern end of Florida Bay is enclosed by the mainland and the Florida Keys, and is influenced by fresh water and terrestrial inputs from the Everglades (Fourqurean et al. 2003). The southwestern regions of Florida Bay are subject to greater oceanic influences, and ecological gradients are well recognized across this regional structure (Boyer et al. 1997, Peterson \& Fourqurean 2001). Table 1 provides a quantitative summary of the gradients associated with some important environmental factors. The east to west gradient in Florida Bay has the potential to affect

Table 1. Examples of important environmental characteristics that display a gradient across Florida Bay with proximate study sites in parentheses (see Fig. 1 for site locations)

\begin{tabular}{|c|c|c|c|c|}
\hline $\begin{array}{l}\text { Environmental or biological } \\
\text { characteristic }\end{array}$ & $\begin{array}{c}\text { Northeast } \\
\text { Florida Bay } \\
\text { (Duck, Nest, } \\
\text { Eagle) }\end{array}$ & $\begin{array}{l}\text { Central } \\
\text { Florida Bay } \\
\text { (Whipray, } \\
\text { Bob Allen, } \\
\text { Barnes) }\end{array}$ & $\begin{array}{c}\text { Western } \\
\text { Florida Bay } \\
\text { (Rabbit, } \\
\text { Johnson, } \\
\text { Arsnicker) }\end{array}$ & Source \\
\hline Average water depth (m) & 1.5 & 2.4 & 3 & Zieman et al. (1989) \\
\hline Average lunar tidal range $(\mathrm{cm})$ & 3 & 17 & 61 & Holmquist et al. (1989) \\
\hline $\begin{array}{l}\text { Maximum sediment depth of basin, } \\
\text { excluding the banktop }(\mathrm{cm})\end{array}$ & 5 & 75 & 300 & Zieman et al. (1989) \\
\hline $\begin{array}{l}\text { Thalassia testudinum leaf C:P ratio interpolated } \\
\text { across Florida Bay (compare to Redfield ratio 106:1) }\end{array}$ & 1) $1600: 1$ & 1200:1 & $800: 1$ & $\begin{array}{l}\text { Frankovich \& } \\
\text { Fourqurean (1997) }\end{array}$ \\
\hline Range in salinity values 1990-1994 (psu) & 42 & 30 & 14 & $\begin{array}{l}\text { Frankovich \& } \\
\text { Fourqurean (1997) }\end{array}$ \\
\hline $\begin{array}{l}\text { Thalassia testudinum green leaf material } \\
\text { per short shoot }\left(\mathrm{mg} \mathrm{ss}^{-1}\right)\end{array}$ & 34 & 100 & 525 & $\begin{array}{l}\text { Frankovich \& } \\
\text { Fourqurean (1997) }\end{array}$ \\
\hline $\begin{array}{l}\text { Average maximum Thalassia testudinum } \\
\text { leaf length }(\mathrm{cm})\end{array}$ & $\begin{array}{c}14.69 \\
(\mathrm{n}=170)\end{array}$ & $\begin{array}{c}23.82 \\
(n=156)\end{array}$ & $\begin{array}{c}34.53 \\
(\mathrm{n}=184)\end{array}$ & $\begin{array}{l}\text { Unpubl. data from } \\
\text { exact sites not presen- } \\
\text { ted in Bricker (2003) }\end{array}$ \\
\hline
\end{tabular}


the genetic structure of subpopulations of organisms that inhabit the ecosystem through differential natural selection pressures. Thalassia testudinum exhibits morphological variation throughout Florida Bay that is hypothesized to be the result of variable environmental conditions (Hackney \& Durako 2004). In addition, T. testudinum is capable of colonizing and expanding to form a new meadow from limited recruitment events. As a result, both abiotic and biotic factors have the potential to influence the genetic structure of local subpopulations. For example, barriers to gene flow such as mud banks, mangrove islands, or even limited water flow through restricted channels could theoretically allow selection for locally adapted genotypes (sensu Linhart \& Grant 1996) across these ecological gradients. If this model is in operation, discrete patterns of gene flow within the ecological zones of the system would be expected. Alternatively, gene flow might occur due to successful adaptation (e.g. buoyant fruits) and the unrestricted recruitment of genotypes (i.e. no selection), resulting in highly-connected subpopulations. This outcome would argue for plasticity being the primary cause of observed morphological variation rather than selection for local adaptation.

Some populations of Thalassia testudinum are largely clonal, while other meadows have high genotypic diversity indicating the presence of many clones (van Dijk \& van Tussenbroek 2010). Differences in the level of genetic diversity detected among populations are presumably due to historical factors. Sexual reproduction has often been conjectured to play a limited role in marine angiosperm life histories due to the scarcity of observations reporting seedling recruitment (Kirkman \& Kuo 1990). For T. testudinum this inference has historically been based upon the stochastic pattern of flowering and fruiting (Lewis \& Phillips 1980). The complex factors affecting sexual reproduction in T. testudinum are being described through ongoing research. For instance, seed set appears enhanced through synchronized anthesis under particular environmental conditions (van Tussenbroek et al. 2008). Adding to the difficulty of studying sexual reproduction in many seagrasses, and T. testudinum in particular, is that fruits are buoyant (Orpurt \& Boral 1964), staying afloat for up to 14 d (Kaldy \& Dunton 1999). Seeds have been observed to settle near the parent (van Dijk et al. 2009) or, as documented off the Yucatan Peninsula, to follow surface currents for many days potentially enabling long distance dispersal (van Dijk et al. 2009). This dispersal mechanism may explain why the dispersal range of aquatic plants such as T. testudinum may be an order of magnitude greater than terrestrial species (Santamaria 2002).

The purpose of the present study was to evaluate genetic structure in Thalassia testudinum populations within Florida Bay and to apply this knowledge to the observed high levels of morphological variation in this species. Gaining insights into the formation and maintenance of $T$. testudinum populations will be valuable to ongoing efforts to preserve and better manage the ecological resources of Florida Bay. Most of Florida Bay is protected by state and federal guidelines designed to protect important or threatened ecosystems within the Everglades National Park. Therefore, Florida Bay, in contrast to other locales that introduce anthropogenic pressure on seagrass populations (Waycott et al. 2009), represents tenable habitat for populations of $T$. testudinum. Thus, this population of seagrass represents an excellent candidate to establish baseline information on population genetics of this important coastal marine species.

\section{MATERIALS AND METHODS}

Study sites and sampling methodology. A synoptic survey of 10 Thalassia testudinum populations was conducted across Florida Bay (Fig. 1). The collection of samples took place on September 6 to 11, 2005. The 10 individual basins were selected to represent ecological gradients along north to south, and east to west vectors (Table 1). The sediments in the northeastern part of Florida Bay are shallow and nutrient poor (Fourqurean et al. 1992, Boyer et al. 1997) while in western areas of the bay they are deeper with higher nutrient levels (Holmquist et al. 1989). Within the target basins, we located areas of sufficient ramet density to support our sampling methodology. We sampled exclusively within the basins avoiding transitionary areas (e.g. bank tops, channels). The precise starting locations within the seagrass meadow were selected haphazardly to reduce the potential for introducing any sampling bias. Once the starting location was established, a boat with a Wide Area Augmentation System (WAAS) enabled GPS unit was set adrift and successive samples were collected at intervals that negated or at least reduced the collection of physically integrated plants (ideally 10 to $30 \mathrm{~m}$ separation between successive samples). However, the direction and speed of the boat was always affected by weather conditions, and sometimes successive pairs of samples were collected as close as $4 \mathrm{~m}$, and as far as $45 \mathrm{~m}$ apart. Sampling at each site consisted of 3 or 4 parallel transect drifts separated by 25 to $50 \mathrm{~m}$, again affected by the local climatic conditions. The individual shoots were bagged and tagged, and the spatial coordinates were recorded for each sample. Therefore spatial distances between all pairs of samples were known.

Microsatellite analysis. DNA was extracted from field-desiccated leaf tissue using a Qiagen DNeasy 


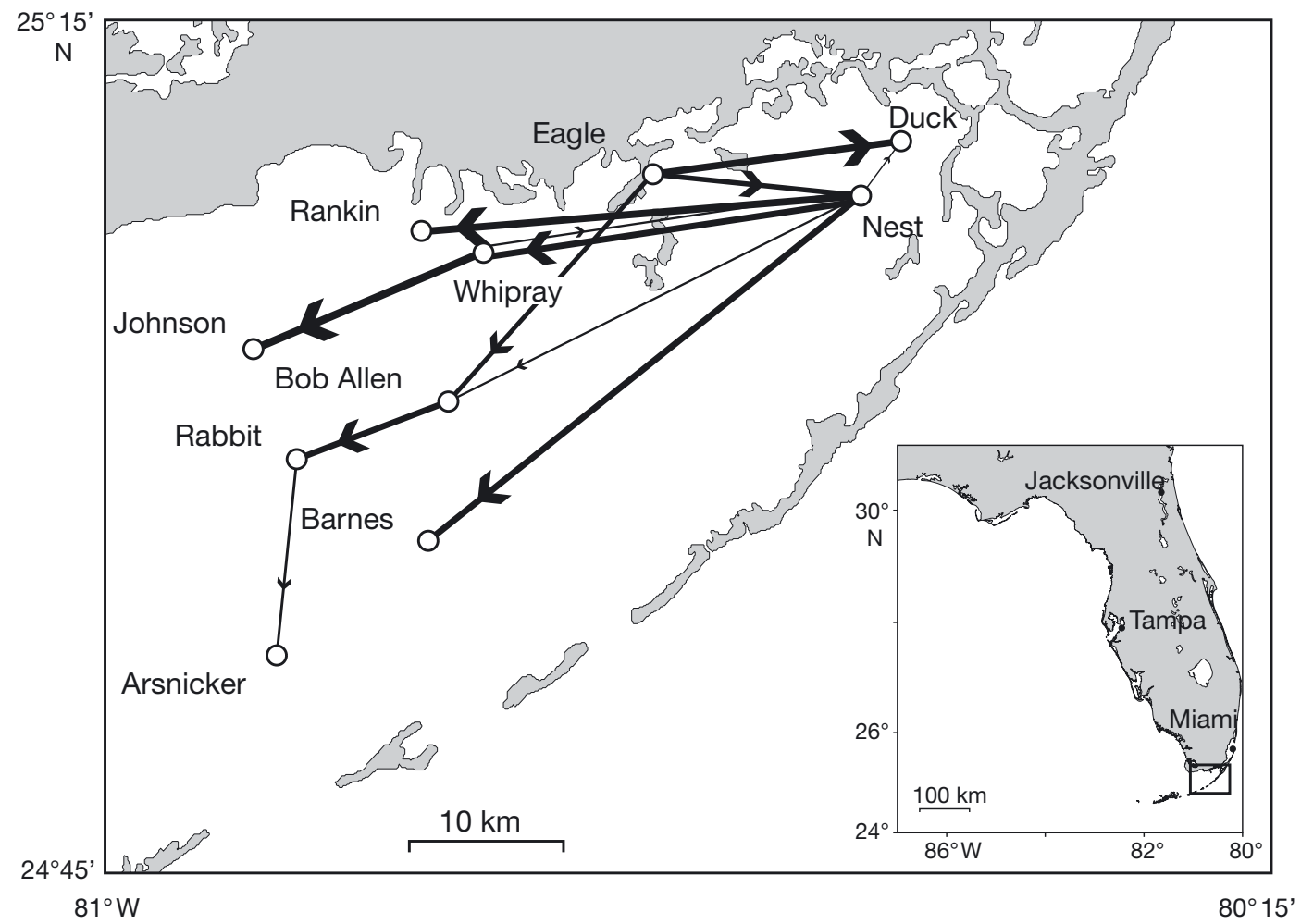

Fig. 1. Thalassia testudinum. Sampling sites overlaid by patterns of migration across Florida Bay, USA. Line thickness indicates the magnitude of the migration rate as modeled using BAYESASS (Wilson \& Rannala 2003) and direction is indicated by the arrowhead

Plant Extraction Kit (Qiagen). Nine microsatellite loci (van Dijk et al. 2007; Table 2) were amplified on a MJ Research PTC-200. Specific primers are listed in Table 2. PCR were performed in $15 \mu$ l reactions containing $30 \mathrm{ng}$ of template DNA, $0.5 \mathrm{U}$ of Bioline Immolase DNA Taq (Bioline), $1.5 \mu \mathrm{l}$ 10× Bioline Immobuffer (160 mM $\left[\mathrm{NH}_{4}\right]_{2} \mathrm{SO}_{4}, 670 \mathrm{mM}$ Tris- $\mathrm{HCl} \mathrm{pH}$ 8.3, $0.1 \%$ Tween-20), $2.5 \mathrm{mM} \mathrm{MgCl}, 0.133 \mathrm{mM}$ each dNTP, BSA at a concentration of $0.1 \mu \mathrm{g} \mathrm{ll}^{-1}$, and $0.33 \mathrm{mM}$ primers; forward primers were labeled with the fluorochromes FAM, HEX or TET (Invitrogen). Thermal cycling proto-

Table 2. Thalassia testudinum. Microsatellite primer summary for 9 loci collected across Florida Bay. Observed heterozygosity $\left(H_{\mathrm{o}}\right)$, expected heterozygosity $\left(H_{\mathrm{e}}\right)$, inbreeding coefficient $\left(F_{\mathrm{IS}}\right)$, and total number of alleles per locus $(A)$

\begin{tabular}{|lcccr|}
\hline Locus & $H_{\mathrm{o}}$ & $H_{\mathrm{e}}$ & $F_{\mathrm{IS}}$ & $A$ \\
\hline Th1 MS & 0.467 & 0.677 & 0.332 & 11 \\
TTMS-GA6 & 0.731 & 0.669 & 0.098 & 13 \\
TTMS-GA8 & 0.674 & 0.669 & 0.018 & 17 \\
TTMS-GA12 & 0.639 & 0.795 & 0.183 & 13 \\
TTMS-TCT58 & 0.615 & 0.598 & 0.016 & 11 \\
TTMS-GGT59 & 0.373 & 0.372 & 0.015 & 9 \\
TTMS-GA72 & 0.581 & 0.570 & 0.023 & 9 \\
TTMS-GT77 & 0.676 & 0.767 & 0.084 & 15 \\
TTMS-GT104 & 0.246 & 0.238 & 0.046 & 6 \\
\hline
\end{tabular}

cols consisted of an initial 14 min denaturing step followed by a 15-cycle touchdown with annealing temperatures from 65 to $50^{\circ} \mathrm{C}$, finishing with 20 cycles at $50^{\circ} \mathrm{C}$. For all cycles denaturing steps were $94^{\circ} \mathrm{C}$ and extension temperature was $72^{\circ} \mathrm{C}$. PCR products were analyzed using a MegaBACE 1000 (GE Biosciences) with ET 400-R internal size standard in each sample, as per manufacturer's instructions. Fragment lengths for each allele, at each locus, were determined using Fragment Profiler software (GE Biosciences).

GenAlEx 6.0 (Peakall \& Smouse 2006) was used to make direct comparisons of genotypes to detect clones, determine the total number of alleles per locus $(A)$, the mean number of alleles per population $(\mathrm{Na})$, the total number of private alleles per population and the analysis of molecular variance (AMOVA). Population migration rates $\left(N_{\mathrm{m}}\right.$ and pairwise population $N_{\mathrm{m}}$ values) were calculated using Genetix 4.05.2 (Belkhir et al. 2004) along with observed $\left(H_{0}\right)$ and expected $\left(H_{\mathrm{e}}\right)$ (unbiased) heterozygosity and Nei's genetic distance (Nei 1978). Genotypic richness $\left(G_{\text {RIC }}\right)$ was calculated manually following Dorken \& Eckert (2001). Allelic richness $\left(A_{\text {RIC }}\right)$, standardized to the smallest population size by rarefaction, was computed using FSTAT 2.9.3.2 (Goudet 1995). Pairwise $F_{\mathrm{ST}}$ and tests of significant differences between pairs were calculated in Arlequin 2.0 (Schneider et al. 2000). All other F sta- 
tistics were calculated using Genetix 4.05.2 (Belkhir et al. 2004).

Pairwise genetic distance (Nei 1972, 1978) and pairwise geographic distance matrices were calculated using GenAlEx 6.0 (Peakall \& Smouse 2006). Spatial autocorrelation was run with the same software using 999 permutations and 999 bootstraps, using even distance classes of an optimized distance size class of $7 \mathrm{~m}$ and a total of 15 distance classes. The size class was based upon the distance interval between successive samples. Wind and water movement resulted in irregular sampling intervals; $7 \mathrm{~m}$ was the interval that ensured that size classes were not empty. The geographic and genetic distance matrices created for the spatial autocorrelation were reconfigured into columns for an isolation by distance test, and analyzed by IBDWS version 3.15 (Jensen et al. 2005) implementing 10000 randomizations.

The number of genetic populations $(K)$ was estimated using STRUCTURE 2.2 (Pritchard et al. 2000). Model optimization resulted in the following parameters: admixture model, inferring alpha (initial alpha 1.0), burn-in period 100 000, and Markov-chain Monte Carlo (MCMC) repetitions after burn-in 150 000. Models were run applying $K=2$ to 20 , however final model runs were $K=2$ to 5 populations with 10 iterations for each value of $K$.

BAYESASS 1.3 (Wilson \& Rannala 2003) was used to estimate recent migration rates; $\sim 25$ preliminary runs were executed to determine the final parameter set. The delta values for allele frequency, migration rate, and inbreeding were kept at the program default (0.15). The burn-in period was set at 2000000 , and the iterations were set to 5000000 . The sampling frequency was set to 1000. Analysis using optimum model parameters showed variability with different initial seed values. To overcome this variance, 75 individual models, each with a different seed, were run. The migration rates were mean values across those 75 runs.

\section{RESULTS}

A total of 657 samples were screened across 9 polymorphic loci, of which 607 samples were identified as unique genotypes. Samples that matched identical alleles at all 9 loci were statistically identified as apparent clones containing fixed heterozygous loci (sibling probability for these ramets ranged from $\mathrm{p}=0.0006$ to $\mathrm{p}=0.003$, meaning a low probability of sharing the exact same alleles, at all loci, as a function of an unrelated genetic descent). In our data set clones typically consisted of 2 ramets; however there were several occurrences where 3 or more ramets were identified as the same genet, and one instance where 5 ramets were detected as a single genet (sibling probability $\mathrm{p}=$ 0.001). The sample population from our study was found to be highly polymorphic (Table 2). Allelic richness, standardized using rarefaction, was 6.62 alleles per locus. Inbreeding coefficients for the individual loci were low, and the inbreeding estimates $F_{\mathrm{IS}}$ for the entire sample set was correspondingly low $\left(F_{\text {IS }}=0.06\right)$. One locus (Table 2, Th1 MS) had a relatively high inbreeding coefficient despite having 11 alleles, suggesting that this was the only locus where some degree of spatial structure and segregation might be occurring. The number of distinct genotypes $(G)$ was proportionally high to the sampling effort as shown by the high $G$ and $G_{\text {RIC }}$ values (Table 3 ). The observed heterozygosity was high at all sites ranging from 0.497 (Rankin) to 0.648 (Arsnicker). Overall the sample population was in Hardy-Weinberg equilibrium across all loci and populations. Allelic richness showed some variability, but was generally comparable among basins ranging from $A_{\text {RIC }}=5.94$ (Eagle) to $A_{\text {RIC }}=7.33$ (Arsnicker). Sites proximate to each other had the lowest pairwise $F_{\mathrm{ST}}$ values (e.g. Eagle-Nest $F_{\mathrm{ST}}=0.024$ ), while sites further away had higher values (e.g. Eagle-Rabbit $\left.F_{\mathrm{ST}}=0.045\right)$, and sites at the greatest distance apart (e.g. Eagle-Arsnicker $F_{\mathrm{ST}}=0.077$ ) had the largest $F_{\mathrm{ST}}$ values (Table 4 ).

No significant isolation by distance was detected across the range of our sample sites $\left(R^{2}=0.007\right)$. AMOVA detected that $94 \%$ of molecular variance for Thalassia testudinum across Florida Bay was partitioned within populations (Table 4). Spatial genetic

Table 3. Thalassia testudinum. Summary of population genetic diversity parameters across Florida Bay (see Fig. 1 for site locations). Number of distinct genotypes $(G)$, genotypic richness $\left(G_{\mathrm{RIC}}\right)$, inbreeding coefficient $\left(F_{\mathrm{IS}}\right)$, observed heterozygosity $\left(H_{0}\right)$, expected (unbiased) heterozygosity $\left(H_{\mathrm{e}}\right)$ (Nei 1987), mean number of alleles averaged across loci $(\mathrm{Na})$, and allelic richness $\left(A_{\mathrm{RIC}}\right)$. N: number of samples

\begin{tabular}{|lrcccccc|}
\hline Population (N) & $G$ & $G_{\mathrm{RIC}}$ & $F_{\mathrm{IS}}$ & $H_{\mathrm{o}}$ & $H_{\mathrm{e}}$ & $\mathrm{Na}$ & $A_{\mathrm{RIC}}$ \\
\hline Arsnicker (30) & 28 & 0.931 & 0.054 & 0.648 & 0.673 & 7.33 & 7.33 \\
Barnes (50) & 44 & 0.878 & 0.105 & 0.509 & 0.562 & 6.56 & 6.00 \\
Nest (55) & 52 & 0.944 & 0.016 & 0.552 & 0.558 & 6.89 & 6.07 \\
Duck (51) & 48 & 0.940 & 0.05 & 0.577 & 0.601 & 7.22 & 6.46 \\
Rabbit (146) & 142 & 0.972 & 0.037 & 0.584 & 0.604 & 9.78 & 6.95 \\
Johnson (75) & 73 & 0.973 & 0.097 & 0.522 & 0.574 & 7.56 & 6.38 \\
Bob Allen (75) & 63 & 0.838 & 0.071 & 0.570 & 0.610 & 7.33 & 6.33 \\
Eagle (75) & 68 & 0.905 & 0.016 & 0.567 & 0.573 & 7.33 & 5.94 \\
Whipray (50) & 46 & 0.918 & 0.097 & 0.531 & 0.582 & 7.33 & 6.77 \\
Rankin (50) & 45 & 0.898 & 0.125 & 0.497 & 0.563 & 6.67 & 6.05 \\
\hline
\end{tabular}


Table 4. Thalassia testudinum. Pairwise comparisons of population differentiation in Florida Bay (see Fig. 1 for site locations) based on multilocus microsatellite genotypes. Below the diagonal: pairwise $F_{\mathrm{ST}}$ (Weir \& Cockerham 1984) values for all populations with significant differences in bold. Along the diagonal: pairwise mean $N_{\mathrm{m}}$ (Wright 1969) values for all populations (SD also shown). Above the diagonal: pairwise $N_{\mathrm{m}}$ values (Wright 1969)

\begin{tabular}{|c|c|c|c|c|c|c|c|c|c|c|}
\hline & Arsnicker & Barnes & Nest & Duck & Rabbit & Johnson & Bob Allen & Eagle & Whipray & Rankin \\
\hline Arsnicker & $\begin{array}{c}4.02 \\
(0.81)\end{array}$ & 3.496 & 3.606 & 3.360 & 5.480 & 4.739 & 4.751 & 3.002 & 4.083 & 3.651 \\
\hline Barnes & 0.067 & $\begin{array}{c}7.69 \\
(2.81)\end{array}$ & 7.663 & 4.793 & 9.938 & 8.046 & 11.404 & 4.692 & 10.630 & 8.563 \\
\hline Nest & 0.065 & 0.032 & $\begin{array}{c}9.64 \\
(3.61)\end{array}$ & 11.446 & 15.171 & 8.103 & 14.220 & 10.099 & 9.466 & 7.012 \\
\hline Duck & 0.069 & 0.050 & 0.021 & $\begin{array}{c}6.99 \\
(2.73)\end{array}$ & 6.950 & 6.083 & 8.082 & 10.160 & 7.995 & 4.037 \\
\hline Rabbit & 0.044 & 0.025 & 0.016 & 0.035 & $\begin{array}{l}12.21 \\
(7.73)\end{array}$ & 11.839 & 30.752 & 5.367 & 12.266 & 12.123 \\
\hline Johnson & 0.050 & 0.030 & 0.030 & 0.040 & 0.021 & $\begin{array}{c}9.93 \\
(6.49)\end{array}$ & 10.880 & 4.752 & 25.945 & 8.960 \\
\hline Bob Allen & 0.050 & 0.022 & 0.017 & 0.030 & 0.008 & 0.023 & $\begin{array}{l}12.64 \\
(7.56)\end{array}$ & 6.627 & 14.395 & 12.641 \\
\hline Eagle & 0.077 & 0.051 & 0.024 & 0.024 & 0.045 & 0.050 & 0.036 & $\begin{array}{c}5.84 \\
(2.67)\end{array}$ & 4.839 & 3.004 \\
\hline Whipray & 0.058 & 0.023 & 0.026 & 0.030 & 0.020 & 0.010 & 0.017 & 0.049 & $\begin{array}{l}11.31 \\
(6.46)\end{array}$ & 12.133 \\
\hline Rankin & 0.064 & 0.028 & 0.034 & 0.058 & 0.020 & 0.027 & 0.019 & 0.077 & 0.020 & $\begin{array}{c}8.01 \\
(3.83)\end{array}$ \\
\hline
\end{tabular}

structure was detected within basins, but only at small spatial scales. The spatial autocorrelation relatedness statistic $r$ was significant between 0 and $75 \mathrm{~m}$, perhaps an indicator of the level of the spatial influence of clonal/vegetative growth. Inbreeding coefficients $\left(F_{\mathrm{IS}}\right)$ were typically low within the basins ranging from pairwise $F_{\mathrm{IS}}=0.02$ (Eagle-Nest) up to pairwise $F_{\mathrm{IS}}=0.13$ (Rankin).

Moderate levels of gene flow $\left(N_{\mathrm{m}}=5.71\right)$ were observed among the sampled meadows of Thalassia testudinum across Florida Bay. When pairwise $N_{\mathrm{m}}$ values were averaged (Table 4), the meadows in the western part of Florida Bay showed the lowest level of gene flow $\left(N_{\mathrm{m}}=4.02\right)$ relative to rest of the study population. The highest levels of gene flow occurred at the central sites $\left(N_{\mathrm{m}}=12.21\right)$.

There was no evidence of genetic differentiation among the entire sample population $\left(F_{\mathrm{ST}}=0.03\right)$. Pairwise comparisons of $F_{\mathrm{ST}}$ values (Table 4 ) showed fairly uniform values between sites and the low $F_{\mathrm{ST}}$ values suggest very little genetic segregation between individual meadows of Thalassia testudinum across Florida Bay.

There was no evidence for the existence of discrete subpopulations based on measures of gene flow and measures of population differentiation (Fig. 2). This model, which applies probability state change as a method of population assignment (i.e. STRUCTURE; Pritchard et al. 2000), could not differentiate our Florida Bay samples into discrete genetic subpopula- tions. This lack of differentiation reflects larger and more historical patterns of population structure. However, the proportion of recent immigrants, inferred using a Bayesian modeling approach as implemented in BAYESASS (Wilson \& Rannala 2003), showed a discernable pattern of directionality in recent migration rates of Thalassia testudinum throughout Florida Bay. These bi-directional migration rates suggested a direction of gene flow that follows a northeast to southwest pattern (Fig. 1, Table 5). While some eastward migration of $T$. testudinum was detected, it was limited to populations located in basins in the north and northeast section of Florida Bay. The BAYESASS analysis suggests that the major proportion of immigrants move outward from Nest and to a lesser extent from Eagle. It is important to reiterate that the lack of detected population structure using $F_{\mathrm{ST}}$ and isolation by distance methods reflects longer term processes versus the detectible migration signal, which represents patterns of recent influences affecting recent migrations.

\section{DISCUSSION}

The data from this study indicate a high level of genetic diversity in the populations of Thalassia testudinum across Florida Bay. All of the loci, screened across all sample populations, were in HardyWeinberg equilibrium. This indicates that evolutionary 


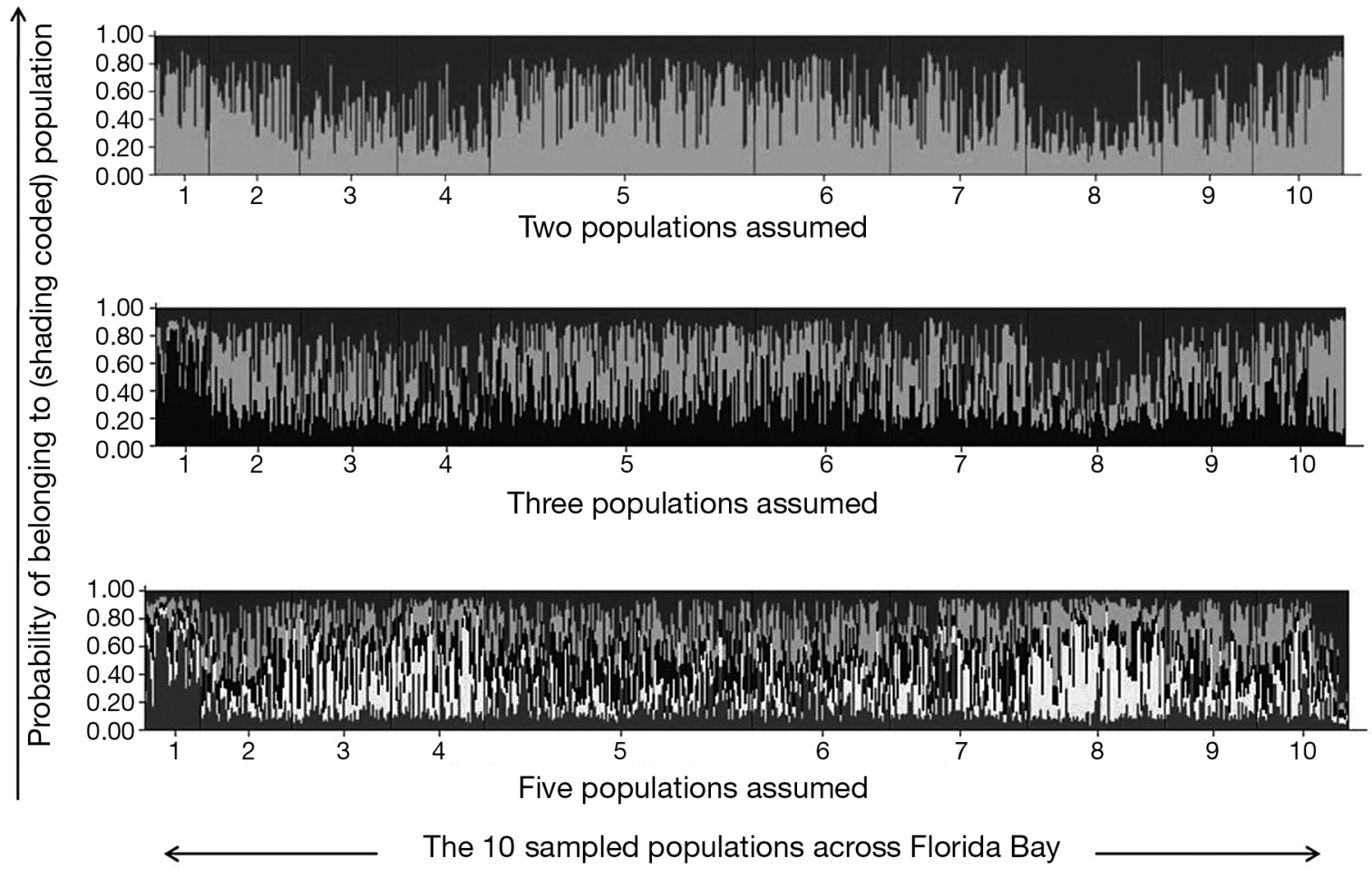

Fig. 2. STRUCTURE (Pritchard et al. 2000) output for Thalassia testudinum across Florida Bay. Plots represent models where different numbers of populations $(K)$ are assumed and modeled. The output on top represents a model where 2 populations were assumed to exist, the middle output represents a model where 3 populations were assumed, and the bottom output represents the model where 5 populations were assumed. The $y$-axis represents the modeled probability of assignment for each sample (ramet) to a specific population. The $x$-axis is a linear continuum of all 627 samples. The signal for population structure would be distinctive regions along the $x$-axis of similarly shaded samples. The shading corresponds to the proportion each individual is assigned to each population group within each model run. Where a mix of shadings occurs, this analysis was not able to precisely assign the sample unambiguously into only one of the populations

Table 5. Thalassia testudinum. BAYESASS model summary for sampling sites across Florida Bay (see Fig. 1). Bold numbers are migration rates averaged from 75 runs, with different initial randomization seeds, that significantly differed from the estimated variance in each run. SDs are given below the average migration rates. Blank cells occur where no significant gene flow was detected consistently among the 75 independent model runs

\begin{tabular}{|c|c|c|c|c|c|c|c|c|c|c|}
\hline & Arsnicker & Johnson & Rabbit & Barnes & Bob Allen & Whipray & Rankin & Eagle & Nest & Duck \\
\hline Arsnicker & $\begin{array}{l}\mathbf{0 . 7 9} \\
0.03\end{array}$ & & & & & & & & & \\
\hline Johnson & & $\begin{array}{l}\mathbf{0 . 6 8} \\
0.01\end{array}$ & & & & & & & & \\
\hline Rabbit & $\begin{array}{l}\mathbf{0 . 1 0} \\
0.04\end{array}$ & & $\begin{array}{l}\mathbf{0 . 7 5} \\
0.05\end{array}$ & & & & & & & \\
\hline Barnes & & & & $\begin{array}{l}\mathbf{0 . 7 2} \\
0.01\end{array}$ & & & & & & \\
\hline Bob Allen & & & $\begin{array}{l}\mathbf{0 . 2 3} \\
0.05\end{array}$ & & $\begin{array}{l}\mathbf{0 . 7 2} \\
0.02\end{array}$ & & & & & \\
\hline Whipray & & $\begin{array}{l}\mathbf{0 . 2 9} \\
0.02\end{array}$ & & & & $\begin{array}{l}\mathbf{0 . 7 3} \\
0.01\end{array}$ & & & $\begin{array}{l}\mathbf{0 . 0 8} \\
0.04\end{array}$ & \\
\hline Rankin & & & & & & & $\begin{array}{c}\mathbf{0 . 7 0} \\
0.008\end{array}$ & & & \\
\hline Eagle & & & & & $\begin{array}{l}\mathbf{0 . 1 7} \\
0.04\end{array}$ & & & $\begin{array}{c}\mathbf{0 . 9 9} \\
0.007\end{array}$ & $\begin{array}{l}\mathbf{0 . 1 9} \\
0.06\end{array}$ & $\begin{array}{c}\mathbf{0 . 2 6} \\
0.038\end{array}$ \\
\hline Nest & & & & $\begin{array}{l}\mathbf{0 . 2 4} \\
0.03\end{array}$ & $\begin{array}{l}\mathbf{0 . 0 8} \\
0.03\end{array}$ & $\begin{array}{c}\mathbf{0 . 2 4} \\
0.024\end{array}$ & $\begin{array}{l}\mathbf{0 . 2 7} \\
0.03\end{array}$ & & $\begin{array}{c}\mathbf{0 . 7 2} \\
0.022\end{array}$ & $\begin{array}{l}\mathbf{0 . 0 5} \\
0.02\end{array}$ \\
\hline Duck & & & & & & & & & & $\begin{array}{c}\mathbf{0 . 6 7} \\
0.007\end{array}$ \\
\hline
\end{tabular}


conditions in Florida Bay are not driving the population of $T$. testudinum to a genetic imbalance through inbreeding or genetic drift. The most important implication of this equilibrium is that evolutionary forces sustain a fairly random pattern of mating for this species. In short, a single or small group of clones has not been dominating population structure within Florida Bay. The limited influence of asexual reproduction over the population structure at the sampled spatial scale is also supported by the levels of gene flow detected. Gene flow was detected at levels that would be classically considered as moderate. These estimates of gene flow clearly support significant connectivity among sampled populations of $T$. testudinum in Florida Bay. Our initial conclusion, when we consider the high degree of system wide connectivity and the lack of population differentiation, is that T. testudinum across Florida Bay does not display a highly clonal signal $\left(G_{\mathrm{RIC}}=0.878\right.$ to 0.973$)$. This finding is in contrast to previous genetic studies of $T$. testudinum in Florida Bay that detected low levels of polymorphism using lower resolution genetic markers (i.e. allozymes, Schlueter \& Guttman 1998). Indeed, the lack of resolution in prior marker systems would have significantly hampered these authors' ability to make meaningful estimates about population structure and encouraged the expectation of highly clonal populations. The comparative resolution of our genetic markers revealed a significantly greater level of polymorphism, indeed limited clonality.

The population of Thalassia testudinum in Florida is highly polymorphic. The levels of allelic richness are also high $\left(A_{\mathrm{RIC}}=5.94\right.$ to 7.33$)$ and our values are comparable to other studies on $T$. testudinum using codominant markers (van Dijk \& van Tussenbroek 2010). Levels of heterozygosity were observed to be consistently high across our study subpopulations $\left(H_{\mathrm{e}}=0.558\right.$ to 0.673 ). The detected levels of polymorphism places T. testudinum as a species with diversity greater than or equal to that of other seagrass species such as Cymodocea nodosa $\left(H_{\mathrm{e}}=0.48\right.$, Alberto et al. 2008), Zostera marina $\left(H_{\mathrm{e}}=0.45\right.$, Olsen et al. 2004), Zostera noltii $\left(H_{\mathrm{e}}=0.452\right.$, Coyer et al. 2004) and Posidonia oceanica $\left(H_{\mathrm{e}}=0.279\right.$ to 0.568 , Serra et al. 2010). We found little evidence to suggest that inbreeding is prevalent $\left(F_{\mathrm{IS}}=0.02\right.$ to 0.13$)$. $T$. testudinum in Florida Bay may be classified as a highly diverse seagrass when compared with the available global data on other seagrass species using equivalent genetic markers. There has been little direct evidence of sexual propagule recruitment into populations despite high levels of sexual reproduction (flowering, fruiting and seed production), although it is postulated to occur (Waycott \& Barnes 2001, Whitfield et al. 2004). This lack of direct evidence for sexual recruitment has lim- ited our understanding of how meadows form and persist. However, the genetic evidence of high levels of sexual propagule recruitment provided by the present study suggests that other processes, such as timing or genet longevity, are the cause of our inability to make these observations, not that they are not occurring.

The targeted population in this study could not be segregated into a series of genetically isolated subpopulations. Low overall $F_{\mathrm{ST}}$ and pairwise $F_{\mathrm{ST}}$ values suggest that there is little population structure, especially one that could be associated with the pervasiveness of clones. We could not find a significant genetic isolation by distance signal. In addition, the lack of broad scale population differentiation was especially clear when levels of gene flow between individual sites (RabbitNest $N_{\mathrm{m}}=15.71$ ) and across the entire population $\left(N_{\mathrm{m}}=5.71\right)$ were considered. We therefore conclude that these results provide compelling evidence that T. testudinum in Florida Bay is a single interbreeding population. If Thalassia testudinum in Florida Bay is acting as a large metapopulation, then the morphological variation displayed by $T$. testudinum across the ecological and environmental gradient is not the result of locally adapted ecotypes. The absence of discrete subpopulations, despite very discrete phenotypes, supports the hypothesis that individual $T$. testudinum genets are capable of highly plastic responses. Phenotypic plasticity, rather than genotypic adaptation to local environmental conditions (subpopulations), thus best describes morphological variation observed in T. testudinum in Florida Bay.

Variability in plant architecture can be significant for this species, especially in Florida Bay. Plants in the northeastern portion of Florida Bay typically have leaves no longer than $8 \mathrm{~cm}$ (Table 1), while plants in the western portion of the bay typically have longer leaf lengths (Hackney \& Durako 2004) sometimes exceeding $50 \mathrm{~cm}$ (Bricker 2003). These observations coupled with our findings suggest Thalassia testudinum has the capacity for genets to adopt a highly plastic growth form, similar to other aquatic plant species (Barrett et al. 1993). Indeed the observed phenotypic responses of T. testudinum in Florida Bay to environmental conditions are plausible, and are supported by the classic work of McMillan \& Phillips (1979), who attributed at least some of the observed morphological variation in 3 species of tropical seagrasses found across wide geographic distances to plasticity. However, in the strict genetic sense, while microsatellites are neutral loci and provide adequate assessment of gene flow, loci specific to the determination of leaf length may be under selection and may be unlinked to the neutral markers described here. We do not believe this is occurring in this system due to the high levels of connectivity detected. Evaluation of morpho-genetic 
traits would permit testing of the linkage between the genetic markers used and observed morphological traits, but that was beyond the scope of this study.

The present findings provide a framework for exploring the origins of the Florida Bay meadows of Thalassia testudinum. The western border of Florida Bay represents the ca. $4500 \mathrm{yr}$ boundary of the now drowned terrestrial system (Scholl et al. 1969). As sea level rise continued following the last glacial maximum, Florida Bay became progressively inundated to its current depth profile (Parker et al. 1955, Scholl et al. 1969, Smith et al. 1989). It is expected that T. testudinum would have kept pace with the development of the bay, colonizing new habitat as it became submerged. This suggests a model where one would expect younger populations to occur in shallower depths located in the northeast portion of the bay. In addition to this direction of colonization, the formation of meadows would have been affected by physical features such as mud banks and mangrove islands that restrict tidal surge. Currently, hydrological flow in Florida Bay is forced by a wind-driven upper water column movement and bulk flow of oceanic-bound water (Nuttle et al. 2000). These interactions create a complex pattern of water motion in the bay. Wind and water movements are the 2 forces that have the potential to affect the dispersal of pollen, fruit, and vegetative fragments. The current results demonstrate a pattern of migration that is outwards from the northeastern portion of the bay westwards and southwards towards the ocean. The pattern of migration (Fig. 1) is more consistent with bulk flow water movement within the bay (Smith 2005), than serial colonization towards the northeast as the bay formed.

We used BAYESASS which utilizes a Bayesian modeling strategy (Wilson \& Rannala 2003) and found an asymmetric pattern of migration. The most distinct example occurred from Nest (Fig. 1), where outward migration was estimated to be in the direction of both western and southwestern basins. In terms of a generalized pattern of outward migration, the northeast section of the bay appears to be important (Fig. 1) with models suggesting emigration out of this area towards western and southern areas of Florida Bay. Due to the conventions of the model these estimates most likely suggest a pattern of recent migration representing up to 4 generations of gene flow. The conundrum to interpreting a time scale for this recent migration is that Thalassia testudinum genet longevity is indeterminate, rendering the time frame of generation length undefined. In addition, fine-scale genetic structure detected by these migration patterns is most likely to be mainly controlled by physical drivers, such as surface and subsurface currents, influencing dispersal of pollen and fruit (Waycott \& Sampson 1997).
In marine systems, unassisted dispersal will primarily occur through water movement; typically hydrological models have not been developed in sufficient detail for this purpose. Broad-scale hydrological models have been utilized to understand environmental conditions (e.g. salinity gradients) throughout Florida Bay, but are insufficient to identify hydrological patterns at the level of detail required to improve our understanding of biological processes. Wind-driven surface currents are most likely to contribute to dispersal of floating fruits in this system. So while there does not appear to be broad-scale impediments to gene flow, complex bathometry, limited connector channels, and complex water flow patterns appear to be affecting specific dispersal vectors (Lewis \& Phillips 1980). It appears that Thalassia testudinum recruitment is strongly linked to these processes and dispersal distances will be a function of the currents present at the time of fruit and seed release. Improved understanding of the origins and efficacy of sexual propagule recruitment along with genet longevity will further resolve population processes in this species.

In summary, Thalassia testudinum in Florida Bay appears to be a single connected metapopulation instead of spatially segregated and genetically distinguishable subpopulations. This seagrass is morphologically variable across Florida Bay; this variation may be interpreted as norms of reaction in a genetically diverse interbreeding population rather than a series of genetically distinct locally adapted ecotypes. The capacity of this species to respond to local conditions through phenotypic plasticity appears significant and must reflect selection for a general purpose genotype or selection for phenotypic plasticity itself (sensu Schlichting 1986). As noted earlier, such an evolutionary strategy likely contributes to $T$. testudinum having a long history in the Atlantic basin given its apparent capacity to adapt to ongoing changes during the past 14 million years of its known species history (Les et al. 2003). Such genomic flexibility as an evolutionary strategy leads to reduction in drivers of speciation and may explain the general low diversity in seagrasses (Waycott et al. 2006).

\section{LITERATURE CITED}

Alberto F, Massa S, Manent P, Diaz-Almela E, Arnaud-Haond S, Duarte CM, Serrao EA (2008) Genetic differentiation and secondary contact zone in the seagrass Cymodocea nodosa across the Mediterranean-Atlantic transition region. J Biogeogr 35:1279-1294

Barrett SCH, Eckert CG, Husband BC (1993) Evolutionary processes in aquatic plant populations. Aquat Bot 44: 105-145

Belkhir K, Borsa P, Chikhi L, Raufaste N, Bonhomme F (2004) GENETIX 4.05.2, Logiciel sous Windows pour la Genei- 
tique des Populations. Laboratoire Genome, Populations, Interactions, CNRS UMR 5171, University de Montpellier Boyer JN, Fourqurean JW, Jones RD (1997) Spatial characterization of water quality in Florida Bay and Whitewater Bay by multivariate analyses: zones of similar influence. Estuaries 20:743-758

Bricker E (2003) An investigation of Thalassia testudinum below-ground structure and productivity. MSc thesis, University of Virginia, Charlottesville, VA

Cook CDK (1985) Range extensions of aquatic vascular plant species. J Aquat Plant Manage 23:1-6

> Coyer JA, Diekmann OE, Serrao EA, Procaccini G and others (2004) Population genetics of dwarf eelgrass Zostera nolti throughout its biogeographic range. Mar Ecol Prog Ser 281:51-62

den Hartog C (1970) Seagrasses of the world. Verh K Ned Akad Wet Afd Naturkd Tweede Reeks 59:1-275

Dorken ME, Eckert CG (2001) Severely reduced sexual reproduction in northern populations of a clonal plant, Decodon verticillatus (Lythraceae). J Ecol 89:339-350

Fourqurean JW, Zieman JC, Powell GVN (1992) Relationships between porewater nutrients and seagrasses in a subtropical carbonate environment. Mar Biol 114:57-65

Fourqurean JW, Durako MJ, Hall MO, Hefty LN (2002) Seagrass distribution in South Florida: a multi-agency coordinated montoring program. In: Porter JW, Porter KG (eds) The Everglades, Florida Bay, and coral reefs of the Florida Keys: an ecosystem sourcebook. CRC Press, Boca Raton, FL, p 497-522

Fourqurean JW, Boyer JN, Durako MJ, Hefty LN, Peterson BJ (2003) Forecasting responses of seagrass distributions to changing water quality using monitoring data. Ecol Appl 13:474-489

Frankovich TA, Fourqurean JW (1997) Seagrass epiphyte loads along a nutrient availability gradient, Florida Bay, USA. Mar Ecol Prog Ser 159:37-50

Goudet J (1995) FSTAT (version 1.2): a computer program to calculate F-statistics. J Hered 86:485-486

> Hackney JW, Durako MJ (2004) Size-frequency patterns in morphometric characteristics of the seagrass Thalassia testudinum reflect environmental variability. Ecol Indic 4:55-71

Holmquist JG, Powell GVN, Sogard SM (1989) Sediment, water level and water temperature characteristics of Florida Bay's grass covered mud banks. Bull Mar Sci 44:348-364

Jensen JL, Bohonak AJ, Kelley ST (2005) Isolation by distance, web service. BMC Genetics 6:13, available at http://ibdws.sdsu.edu/

Kaldy JE, Dunton KH (1999) Ontogenetic photosynthetic changes, dispersal and survival of Thalassia testudinum (turtle grass) seedlings in a sub-tropical lagoon. J Exp Mar Biol Ecol 240:193-212

Kirkman H, Kuo J (1990) Pattern and process in southern Australian seagrasses. Aquat Bot 37:367-382

> Les DH, Cleland MA, Waycott M (1997) Phylogenetic studies in alismatidae, II: Evolution of marine angiosperms (seagrasses) and hydrophily. Syst Bot 22:443-463

Les DH, Crawford DJ, Kimball RT, Moody ML, Landolt E (2003) Biogeography of discontinuously distributed hydrophytes: a molecular appraisal of intercontinental disjunctions. Int J Plant Sci 164:917-932

> Lewis RR, Phillips RC (1980) Occurrence of seeds and seedlings of Thalassia testudinum Banks ex König in the Florida Keys (USA). Aquat Bot 9:377-380

Linhart Y, Grant M (1996) Evolutionary significance of local genetic differentiation in plants. Annu Rev Ecol Syst 27: $237-277$
Madden CJ, Rudnick DT, McDonald AA, Cunniff KM, Fourqurean JW (2009) Ecological indicators for assessing and communicating seagrass status and trends in Florida Bay. Ecol Indic 9:S68-S82

> McMillan C, Phillips RC (1979) Differentiation in habitat response among populations of new world seagrasses. Aquat Bot 7:185-196

- McQuaid CD, Phillips TE (2000) Limited wind-driven dispersal of intertidal mussel larvae: in situ evidence from the plankton and the spread of the invasive species Mytilus galloprovincialis in South Africa. Mar Ecol Prog Ser 201: 211-220

Moore DR (1963) Distribution of the seagrass, Thalassia, in the United States. Bull Mar Sci Gulf Caribb 13:329-342

> Nei M (1972) Genetic distance between populations. Am Nat 106:283-292

Nei M (1978) Estimation of average heterozygosity and genetic distance from a small number of individuals. Genetics 89:583-590

> Nuttle WK, Fourqurean JW, Cosby BJ, Zieman JC, Robblee MB (2000) Influence of net freshwater supply on salinity in Florida Bay. Water Resour Res 36:1805-1822

> Olsen JL, Stam WT, Coyer JA, Reusch TBH and others (2004) North Atlantic phylogeography and large-scale population differentiation of the seagrass Zostera marina L. Mol Ecol 13:1923-1941

Orpurt PA, Boral LL (1964) The flowers, fruits and seeds of Thalassia testudinum König. Bull Mar Sci Gulf Caribb 14: 296-302

Parker GG, Ferguson GE, Love SK (1955) Water resources of southeastern Florida, with special reference to the geology and ground water of the Miami area. U.S. Geological Survey Water-Supply Paper 1255, Washington, DC

Peakall R, Smouse PE (2006) GENALEX 6: genetic analysis in Excel. Population genetic software for teaching and research. Mol Ecol Notes 6:288-295

Peterson BJ, Fourqurean JW (2001) Large-scale patterns in seagrass (Thalassia testudinum) demographics in South Florida. Limnol Oceanogr 46:1077-1090

Planes S, Jones GP, Thorrold SR (2009) Larval dispersal connects fish populations in a network of marine protected areas. Proc Natl Acad Sci USA 106:5693-5697

Pritchard JK, Stephens M, Donnelly P (2000) Inference of population structure using multilocus genotype data. Genetics 155:945-959

$>$ Reusch TBH, Bostrom C, Stam WT, Olsen JL (1999) An ancient eelgrass clone in the Baltic. Mar Ecol Prog Ser 183: 301-304

Santamaria L (2002) Why are most aquatic plants widely distributed? Dispersal, clonal growth and small-scale heterogeneity in a stressful environment. Acta Oecol Int J Ecol 23:137-154

Schlichting CD (1986) The evolution of phenotypic plasticity in plants. Annu Rev Ecol Syst 17:667-693

Schlueter MA, Guttman SI (1998) Gene flow and genetic diversity of turtle grass, Thalassia testudinum, banks ex könig, in the lower Florida Keys. Aquat Bot 61:147-164

Schneider S, Roessli D, Excoffier L (2000) Arlequin: a software for population genetic data. Genetics and Biometry Laboratory, University of Geneva

> Scholl DW, Craighead FC, Stuiver M (1969) Florida submergence curve revised: Its relation to coastal sedimentation rates. Science 163:562-564

Sculthorpe CD (1967) The biology of aquatic vascular plants. Edward Arnold, London

Serra IA, Innocenti AM, Di Maida G, Calvo S and others (2010) Genetic structure in the Mediterranean seagrass 
Posidonia oceanica: disentangling past vicariance events from contemporary patterns of gene flow. Mol Ecol 19: $557-568$

Smith NP (2005) Transport through Tavernier Creek: a primary flushing pathway for northeast Florida Bay. Ocean Dyn 55:449-457

Smith TJ III, Hudson JH, Robblee MB, Powell GVN, Isdale PJ (1989) Freshwater flow from the Everglades to Florida Bay: a historical reconstruction based on fluorescent banding in the coral Solenastrea bournoni. Bull Mar Sci 44:274-282

van Dijk JK, van Tussenbroek BI (2010) Clonal diversity and structure related to habitat of the marine angiosperm Thalassia testudinum along the Atlantic coast of Mexico. Aquat Bot 92:63-69

van Dijk JK, Waycott M, Van Tussenbroek BI, Ouborg J (2007) Polymorphic microsatellite markers for the Caribbean seagrass Thalassia testudinum Banks ex König. Mol Ecol Notes 7:89-91

van Dijk JK, van Tussenbroek BI, Jimenez-Duran K, Marquez-Guzman GJ, Ouborg J (2009) High levels of gene flow and low population genetic structure related to high dispersal potential of a tropical marine angiosperm. Mar Ecol Prog Ser 390:67-77

van Tussenbroek BI, Vonk JA, Stapel J, Erftemeijer PLA, Middelburg JJ, Zieman JC (2006) The biology of Thalassia: Paradigms and recent advances in research. In: Larkum AWD, Orth RJ, Duarte CM (eds) Seagrasses: biology, ecology, and conservation. Springer, Dordecht, p 409-439

van Tussenbroek BI, Wong JGR, Marquez-Guzman J (2008) Synchronized anthesis and predation on pollen in the marine angiosperm Thalassia testudinum (Hydrochari-

Editorial responsibility: Kenneth Heck,

Dauphin Island, Alabama, USA taceae). Mar Ecol Prog Ser 354:119-124

Waycott M, Barnes PAG (2001) AFLP diversity within and between populations of the Caribbean seagrass Thalassia testudinum (Hydrocharitaceae). Mar Biol 139:1021-1028

- Waycott M, Sampson JF (1997) The mating system of an hydrophilous angiosperm Posidonia australis (Posidoniaceae). Am J Bot 84:621-625

Waycott M, Procaccini G, Les DH, Reusch TBH (2006) Seagrass evolution, ecology, and conservation: a genetic perspective. In: Larkum AWD, Orth RJ, Duarte CM (eds) Seagrasses: biology, ecology, and conservation. Springer, Dordecht, p 25-50

> Waycott M, Duarte CM, Carruthers TJB, Orth RJ and others (2009) Accelerating loss of seagrasses across the globe threatens coastal ecosystems. Proc Natl Acad Sci USA 106:12377-12381

Weir BS, Cockerham CC (1984) Estimating F-statistics for the analysis of population-structure. Evolution 38:1358-1370

Whitfield PE, Kenworthy WJ, Durako MJ, Hammerstrom KK, Merello MF (2004) Recruitment of Thalassia testudinum seedlings into physically disturbed seagrass beds. Mar Ecol Prog Ser 267:121-131

- Wilson GA, Rannala B (2003) Bayesian inference of recent migration rates using multilocus genotypes. Genetics 163: $1177-1191$

Wright S (1969) Evolution and the genetics of populations: the theory of gene frequencies, Vol 2. The University of Chicago Press, Chicago, IL

Zieman JC, Fourqurean JW, Iverson RL (1989) Distribution, abundance and productivity of seagrasses and macroalgae in Florida Bay. Bull Mar Sci 44:292-311

Submitted: August 18, 2010; Accepted: November 27, 2010

Proofs received from author(s): January 31, 2011 